\title{
Método de análise e crítica de tradução de Antoine Berman: Autorresenha do seu livro Por uma crítica da tradução: John Donne ${ }^{1}$
}

Marie Helene C. Torres*

Vous me trouvez idiot? $C^{\prime}$ est parce que je suis en train d'échanger des idées avec vous. Paul Claudel

Como especificado por Isabelle Berman no prefácio, o livro Pour une critique des traductions: John Donne publicado em 1995 é um livro póstumo de Antoine Berman, que faleceu no dia 22 de novembro de 1991. Num artigo publicado na revista PoEsie em 1992, artigo também publicado post mortem, Berman faz o que chamo de autorresenha do seu próprio livro, Pour une critique des traductions: John Donne, isto é, um breve resumo do livro com análises dos pontos que considerava essenciais à crítica. Apesar destas duas publicações totalmente anacrônicas - o livro foi escrito em 1989 para uma síntese sobre as suas pesquisas a pedido da Universidade -, Berman é ao mesmo tempo autor e crítico de si próprio.

Neste sentido, as páginas a seguir retomam não somente a autorresenha de Berman, mas também incorporam o seu pensamento teórico desenvolvido no livro. Estas tomam as características ao mesmo tempo de

\footnotetext{
${ }^{1}$ Traduzi o título do livro em português, apesar de não ter tradução até hoje. Quanto ao artigo publicado em 1992 e intitulado "Critique des traductions/John Donne", a revista francesa não cedeu os direitos de tradução à revista Cadernos de Tradução porque Cadernos é uma "revista de acesso gratuito, em open access na internet, sem proteção de senha". O livre acesso impede paradoxalmente a divulgação e tradução do pensamento de Antoine Berman no Brasil.

Artigo de Berman em livre acesso e sem senha do site da revista francesa: https://po-et-sie.fr/numero/59/ * PGET/UFSC; POET/UFC; CNPq
} 
uma "pseudorresenha" pela liberdade ensaística que o gênero possibilita e de uma reescrita produtiva em português, emprestando o qualificativo a Berman, dos textos que escreveu em francês. Entendo o texto que apresento aqui para o leitor como uma atividade processual do reescrever que me fez considerar o fato de que as condições de circulação de um texto fazem parte integrante de sua produção. Trato somente das primeiras partes da autorresenha e do livro dedicados especificamente ao seu método de análise e crítica das traduções.

Será principalmente no intuito de elaborar uma crítica das traduções que Berman propôs o que ele mesmo intitulou de esboço de um método. Crítica no sentido de análise minuciosa de uma tradução, bem como seus traços característicos fundamentais, o projeto inicial, o horizonte que o viu surgir, a posição do tradutor. Berman se utiliza de dois modelos de crítica, duas formas de crítica existente de análise ou de crítica de tradução, a de Meschonnic e a de Toury. Considerava a forma de crítica de Meschonnic como negativa e até mesmo polêmica, por ser unilateral e, como diz, injusta dentro de sua própria retidão. Reconhece que Meschonnic fazia análises comparativas, mas que essas confrontações microscópicas e concisas de fragmentos do original com fragmentos da tradução eram um mero alinhamento arbitrário de pequenas observações. Quanto a Toury, da escola de Tel Aviv, Lambert da escola de Leuven, ou ainda Brisset de Ottawa ou Snell-Horby da Áustria, eles desenvolveram, segundo Berman, uma "sociocrítica das traduções" que analisa textos de literatura traduzida, a qual inspirou o seu método.

Desenvolvo meu texto seguindo o que Berman chama de "trajeto analítico", detalhando cada etapa para demostrar e sistematizar os procedimentos do método de análise crítica. A primeira parte concerne à etapa preliminar, ou seja, à pré-análise da tradução e do original a partir da leitura e seleção de exemplos textuais estilísticos. A segunda parte se interessa pelo perfil do tradutor que Berman concebe como autor do texto traduzido, isto é, o sujeito traduzinte. À maneira dos teóricos descritivistas, Berman procura saber, baseando-se em três categorias hermenêuticas, quem é o tradutor e qual sua posição tradutiva, seu projeto de tradução e o seu horizonte de tradução. Na última parte, descrevo a análise comparativa, ou 
melhor, a confrontação da tradução e do original e o julgamento de valor da tradução apresentado por Berman.

\section{Pré-análise da tradução}

É lendo e relendo, juntas ou separadas, as sucessivas versões dessa tradução e efetuando um vai-e-vem entre essas versões e o original, aproximadamente na ordem que será descrita, que nós aprendemos a ler uma tradução, afirma Berman. O primeiro ato do crítico consiste em suspender qualquer julgamento apressado e em se comprometer com um longo e minucioso trabalho de leitura e releitura da tradução ou das traduções. A primeira leitura permanece ainda, inevitavelmente, aquela de uma "obra estrangeira" em francês, avisa Berman. A segunda lê a obra como uma tradução, o que implica uma conversão do olhar. Berman recomenda que, nessa etapa de leitura e releitura, o crítico deixe o original inteiramente de lado para resistir à compulsão da comparação. Porque somente essa leitura da tradução permite detectar se o texto traduzido "funciona" como um texto escrito na língua receptora, ou seja, essencialmente, não estar aquém das normas de qualidade da escrita padrão. Significa simplesmente que está "bem escrito" na língua de chegada, a língua da tradução.

É somente através dessas diversas leituras que o crítico descobre quais os graus de consistência imanente do texto traduzido, fora de qualquer relação com o original. Segundo Berman, essas releituras apontam também as "zonas textuais" problemáticas: de repente, o texto traduzido parece se enfraquecer, se contradizer, perder o ritmo, parece demasiado fácil, impessoalmente francês; ou, o texto traduzido exibe com brutalidade palavras, formas frasais, que destoam; e ainda, o texto traduzido se mostra invadido por modismos, remetendo à língua do original, o que testemunha o fenômeno de contaminação linguística ou de interferência. Essas leituras e releituras, diz Berman, podem revelar uma escrita de tradução, uma escrita que nenhum escritor francês poderia ter escrito, uma escrita de estrangeiro harmoniosamente passada para o francês. Essas zonas textuais, nas quais o tradutor escreveu "estrangeiro em francês" e assim produziu um francês novo, são as zonas de graça e riqueza do texto traduzido. São essas 
"impressões" de leitura que vão, segundo Berman, orientar o trabalho analítico do crítico: "Nós lemos e relemos a tradução, formamos uma impressão (ou uma impressão se formou em nós). É necessário agora tornar, ou re-tornar, ao original"2 (BERMAN, 1995, p. 67).

As leituras do original podem ser acompanhadas de "leituras colaterais", segundo expressão do Berman: leituras das demais obras de um autor, leitura de outras traduções do tradutor, leituras críticas, informativas, etc. Essas leituras colaterais devem intervir um pouco depois das duas primeiras leituras fundamentais, afirma. Ler o original, por sua vez, implica deixar de lado a tradução. Mas o crítico não deve esquecer as zonas textuais nas quais a tradução pareceu às vezes problemática, às vezes bem-sucedida. Ele as lê, relê, as grifa, em preparação da futura confrontação.

Da simples leitura cursiva, a leitura do original tomará rapidamente a forma de pré-análise textual, ou seja, uma espécie de rastreamento de todos os traços estilísticos que singularizam a escrita e a língua do original e que os torna uma rede de correlações sistemáticas. Berman alerta que não se trata de um processo exaustivo. Funciona do seguinte modo: a leitura trata de reconhecer tal tipo de forma de frase, de significados de sequências proposicionais, tipos de emprego do adjetivo, do advérbio, do tempo verbal, das preposições etc. Ela revela as palavras recorrentes, as palavras-chave, o que inclui todas as redes de significantes, de termos, de conceitos e redes metafóricas da obra, frequentemente descuidadas pelos tradutores.

Mais globalmente, a leitura do original procura determinar como se vincula, na obra, a escrita à língua, quais ritmos o texto traz na sua totalidade. Berman observa a esse respeito que "Aqui, o crítico refaz o mesmo trabalho de leitura que o tradutor fez, ou que supostamente fez, antes e durante a tradução"3 (1995, p. 67). E ele especifica em seguida que não é exatamente o mesmo, pois a leitura do tradutor, como sublinhou em A prova do estrangeiro, remetendo a Schleiermacher, é uma pré-tradução, uma leitura efetuada no horizonte da tradução. A análise da tradução pelo crítico não é mera e

\footnotetext{
2 « Nous avons lu et relu la traduction; nous nous sommes fait une impression (ou une impression s'est faite en nous). Il faut maintenant nous tourner, ou nous re-tourner, vers l'original. »

${ }^{3}$ « Ici, le critique refait le même travail de lecture que le traducteur a fait, ou est censé avoir fait, avant et pendant la traduction. »
} 
simplesmente fundamentada na confrontação do tradutor com a obra. É necessário que ele recorra a múltiplas leituras colaterais, a outras obras do autor, a trabalhos diversos sobre esse autor, a estudos sobre sua época etc.

De uma maneira geral, traduzir exige leituras vastas e diversificadas. E Berman acrescenta que um tradutor ignorante - que não lê tanto assim - é um tradutor deficiente. Traduz-se com livros e não unicamente com dicionários! Ele chama esse necessário recurso às leituras de escoramento do ato tradutório, isto é, todos os paratextos que venham a sustentar a leitura: introdução, prefácio, posfácio, notas, glossários etc. A tradução não pode estar "nua", sob pena de não levar a cabo a tradução literária, avisa Berman. Porém ele não quer ser prescritivo e afirma que a análise textual não é imprescindível e que ela é uma ferramenta de apoio para qualquer trabalho de tradução. Não quer dizer "o que é necessário fazer" e afirma que não pretende regrar a prática da tradução. A pré-análise consiste na leitura da tradução pelo crítico, porque tem apenas a função de preparar a confrontação. Essas leituras são mais interligadas e mais sistemáticas do que as do tradutor.

Com a pré-análise e as leituras que a acompanham, começa um longo trabalho de seleção de exemplos estilísticos pertinentes e significativos no original. O rigor da confrontação, exceto no caso de um texto curto no qual tudo é analisado, deve necessariamente se apoiar sobre exemplos. O recorte textual é um momento delicado e essencial para Berman. São selecionadas, recortadas também e, dessa vez, a partir de uma interpretação da obra, que vai variar de acordo com os críticos, as passagens do original onde ela se condensa, representa, significa ou simboliza. Essas passagens são o que Berman chama de zonas significantes, nas quais uma obra atinge a própria finalidade. Adverte ainda que essas passagens não são necessariamente aparentes numa simples leitura. É o trabalho interpretativo que as revela ou confirma a sua existência: num poema, pode ser um verso; num romance, algumas passagens; num conjunto de contos, a frase final da última narrativa; numa peça de teatro, uma ou duas contrapartes que, de uma só vez nos dizem o sentido de toda a obra de maneira precisa.

Para Berman, diferentemente dos excertos de antologias clássicas, essas passagens não são obrigatoriamente passagens estéticas, mas sim as 
que manifestam a significância da obra numa escrita que possui o mais elevado grau de necessidade possível. Todas as outras partes da obra possuem, em graus diversos, um caráter aleatório, já que poderiam sempre ter sido escritas de forma diferente. Isso vale até mesmo para qualquer poema aparentemente perfeito. O comprovam os rascunhos, as versões, os registros e outras variações de um texto literário. E qualquer que seja o grau final de sistematicidade e unidade de uma obra, a obra comporta por essência as partes aleatórias. Se a proporção do aleatório é muito grande, ou melhor, se o peso do aleatório é mais do que o necessário, a obra é afetada. Se, pelo contrário, a proporção do necessário se impõe sobre o aleatório, a obra é ameaçada por certo formalismo monológico. Berman considera que essa dialética do necessário e do aleatório é determinante para a crítica e para o tradutor. É o que Genette chama de ideia de intangibilidade do texto poético ou literário, que é geralmente ligada à intraduzibilidade. Berman afirma ainda que a coexistência de elementos intangíveis e elementos tangíveis em uma obra é muito importante para o tradutor.

Após a pré-análise textual que selecionou diversos traços estilísticos fundamentais do original e que a partir da interpretação da obra permitiu uma seleção das suas passagens significativas, segundo Berman, o crítico de tradução penetra no texto traduzido, localiza as suas zonas fracas e as suas zonas fortes, analisa e interpreta o original e constitui um material textual de exemplos exaustiva, racional e representativa. E antes da confrontação do original e da tradução, para entender o funcionamento e lógica do sistema da tradução, o crítico deve se interessar não somente pelo trabalho de tradução, mas também pelo tradutor.

\section{O tradutor e o trabalho de tradução}

Conforme Berman, uma das tarefas de uma hermenêutica do traduzir é ter em vista o sujeito que traduz, por isso, vai em busca do tradutor. Assim, a pergunta "quem é o tradutor?" deve ser colocada frente a uma tradução. Essa pergunta é diferente da pergunta feita ao autor de uma obra literária, “quem é o autor?", pois visa aos elementos biográficos, psicológicos, 
existenciais etc., que supostamente irão iluminar a sua obra. Apesar da obra e da existência estarem ligadas.

A pergunta "quem é o tradutor?" tem uma outra finalidade. Salvo exceções, como São Jerônimo por exemplo, para Berman, a vida do tradutor não nos diz respeito e, menos ainda, os seus estados de alma. Não obstante, é impensável que o tradutor permaneça este perfeito desconhecido que é na maior parte do tempo. Berman atesta que importa saber se o tradutor é francês ou estrangeiro, se é somente tradutor ou se exerce outra profissão significativa, como a de professor (caso de uma importante parcela dos tradutores literários na França); quer saber ainda se é também autor, se produziu obras, de quais línguas ele traduz, que ligações mantém com as mesmas; se é bilíngue, e de que tipo, que tipos de obras traduz geralmente e quais outras obras traduziu; se é politradutor (que traduz de várias línguas) ou monotradutor (que traduz textos de uma única língua). Importa também saber quais são seus domínios linguísticos e literários; se faz obras de tradução no sentido mais elevado e quais são as suas principais traduções; se escreve artigos, estudos, teses, livros sobre as obras que traduziu e, por último, se escreve sobre a sua prática de tradutor, os princípios que o guiam, as suas traduções e a tradução em geral. Todos esses questionamentos, não exaustivos, ajudarão o crítico a determinar a posição do tradutor na tradução, o seu projeto de tradução e o seu horizonte tradutório.

Qualquer tradutor, segundo Berman, mantém uma ligação específica com a sua própria atividade, ou seja, tem certa concepção ou percepção do traduzir, de seu sentido, das suas finalidades, das suas formas e modos. O tradutor é marcado de forma efetiva, explica, por todo um discurso histórico, social, literário, ideológico sobre a tradução e a escrita literária.

A posição tradutória é, por assim dizer, o compromisso entre a maneira na qual o tradutor toma consciência da sua tarefa da tradução e a maneira como ele internaliza o discurso sobre o traduzir. A posição tradutória é o que o tradutor se impõe em vista da tradução. Berman afirma, ainda, que é elaborando uma posição tradutória que a subjetividade do tradutor se constitui e adquire a sua espessura significante clara, porém sempre ameaçada, por três perigos maiores: a falta de forma camaleônica, a liberdade caprichosa e a tentação de apagar. Não há tradutor sem posição 
tradutória, afirma Berman. Mas há tantas posições tradutórias quanto tradutores! O papel do crítico é o de reconstituir essas posições a partir das traduções e das diversas falas que o tradutor faz acerca de suas traduções, do traduzir ou de outros temas. Quando captar no tradutor ao mesmo tempo a posição tradutória, a posição linguística (suas referências às línguas estrangeiras e à língua materna) e a posição de escrita (sua ligação com a escrita e as obras), uma teoria do sujeito tradutor, segundo Berman, será possível.

O conceito de projeto de tradução que Berman toma emprestado a Daniel Gouadec foi utilizado pela primeira vez por ele em 1988 no evento ATLAS ("Assises de la Traduction Littéraire") como autocitado no seu livro (1995, p. 76):

\footnotetext{
Numa tradução bem-sucedida, a união da autonomia e da heteronomia só pode resultar no que se poderia chamar de um projeto de tradução, que não tem necessidade de ser teórico. [...] O tradutor pode determinar a priori qual será o grau de autonomia ou heteronomia que atribuirá à sua tradução e isso sobre a base de uma pré-análise - digo pré-análise porque nunca se tem um texto realmente analisado antes de traduzi-lo - do texto a ser traduzido.
}

Toda tradução, consequentemente, é conduzida por um projeto ou uma finalidade articulados. O projeto (ou finalidade) é determinado, por sua vez, pela posição tradutória e por exigências específicas colocadas pela obra a ser traduzida. Não há necessidade de serem enunciados discursivamente e, depois, teorizados. $\mathrm{O}$ projeto define a maneira pela qual, por um lado, o tradutor vai efetuar a translação literária e, de outra parte, assumir a própria tradução, escolher um "modo" de tradução, uma "maneira de traduzir". Para ilustrar o seu argumento, Berman pega o caso dos tradutores que decidiram tornar conhecida na França a obra poética de Kathleen Raine. Poderiam escolher entre várias possibilidades: fazer uma "antologia" dos poemas de Raine a partir de seus livros ou editar seus livros - todos ou parte deles. Escolheram traduzir vários dos seus livros integralmente. Poderiam ainda propor uma edição monolíngue (francês apenas) ou bilíngue. Escolheram a segunda possibilidade. Poderiam, finalmente, apresentar uma edição "nua", sem paratextos (introdução etc.), ou uma edição com 
paratextos. Escolheram a segunda possibilidade. Isso é o projeto de tradução literária daqueles tradutores. Além disso, o estudo das suas traduções (e apenas das traduções, já que não há nenhuma menção, nos paratextos, do trabalho tradutório) revela o modo de tradução escolhido, a maneira de traduzir, que é a segunda face do projeto.

O crítico de tradução deve ler a tradução a partir do seu projeto, mas a verdade desse projeto só é acessível a partir da própria tradução, pois o que um tradutor pode dizer e escrever a propósito do seu próprio projeto só pode ser verificado ao analisar a tradução. Portanto, a tradução é a realização do projeto e revela como foi realizado e quais foram as consequências do projeto em relação ao original.

Com o conceito de horizonte, Berman confessa que quer escapar do funcionalismo ou do estruturalismo que reduzem o tradutor ao papel de um retransmissor inteiramente determinado socioideologicamente e que, além disso, reduzem o real aos encadeamentos de leis e de sistemas. Aqui está a questão, como dizem Ricoeur e Jauss, de horizonte, de experiência, de mundo, de ação e de recontextualização, todos os conceitos fundamentais da hermenêutica moderna, estreitamente correlacionados, e que têm a mesma dualidade: são conceitos ao mesmo tempo objetivos e subjetivos, positivos e negativos, que apontam todos para uma finitude e uma infinitude.

Berman avisa que essas afirmações podem chocar os que confundem projeto com projeto teórico ou esquema a priori. É evidente que qualquer projeto inteiramente esclarecido e determinado se torna, ou corre o risco de se tornar, rígido e dogmático. Assim, a regra cada vez mais aceita é que uma palavra marcada no original deve sempre corresponder a uma palavra no texto traduzido, independentemente do "contexto". E, mais uma vez, Berman ilustra seu argumento, dizendo que, quando Georg Trakl emprega o adjetivo leise nos seus poemas, é necessário sempre traduzi-lo de forma idêntica, porque se trata de um adjetivo fundamental para ele. Ocorre o mesmo com gerne em Hölderlin ou because em Faulkner. A regra, na opinião do Berman, deixa de ser absolutamente válida quando, em virtude da presença dos elementos aleatórios ou estereotipados que existem em qualquer texto, uma palavra-chave perde temporariamente seu caráter marcado. E acrescenta 
que, além da reflexão, o tradutor pode considerar o caráter imediato e intuitivo do traduzir.

Posição tradutória e projeto de tradução, por sua vez, são tomados num horizonte. Berman toma emprestada a palavra e o conceito à hermenêutica moderna desenvolvida por Husserl e Heidegger e define o horizonte da tradução como o conjunto dos parâmetros da linguagem, literários, culturais e históricos que "determinam" o sentir, o agir e o pensar de um tradutor. Explana que coloca "determinam" entre aspas porque não se trata de simples determinações no sentido de condicionamentos, pois esses são pensados de maneira causal ou de maneira estrutural.

Para exemplificar sua afirmação, Berman dá como exemplo a retradução em francês em 1991 de Safo por Philippe Brunet. Segundo ele, o horizonte de sua retradução, aquele a partir do qual Brunet retraduziu Safo, se define pelo saber sobre a poesia lírica grega na França, remetendo à Grécia Antiga e à Antiguidade grega e romana em geral, sem esquecer que, naquela época na França, publicou-se muitos trabalhos de historiadores sobre poetas gregos e romanos. Tudo isso atesta, segundo Berman, que usa a expressão de Jauss, a existência de certo "horizonte de expectativa" de um determinado público francês voltado para a questão grega e romana. Daí, o tradutor pode recorrer, eventualmente, a formas de poesia lírica anteriores para retraduzir Safo. Há ainda a totalidade das traduções existentes de Safo na França desde o século XVI, que o tradutor pode escolher ler ou não. Todos os parâmetros elencados, mas não exaustivos, formam o horizonte obrigatório e plural do tradutor de Safo. A noção de horizonte tem uma dupla natureza. De um lado, designa aquilo a partir do que o agir do tradutor tem sentido e pode se expandir, aponta o espaço aberto desse agir. Mas, de outro lado, designa aquilo que fecha o tradutor num círculo de possibilidades limitadas. Está assim definida a terceira etapa do percurso detalhado por Berman, como acabamos de ver, e que se articula em três momentos: o estudo da posição tradutória, o estudo do projeto de tradução e o estudo do horizonte tradutório.

Estes momentos não ocorrem linearmente, diz Berman. A análise do horizonte é - a princípio - preliminar, e a da posição tradutória e a do projeto dificilmente podem ser separadas. A análise do projeto em si, em 
virtude do círculo evocado acima, comporta duas fases. A primeira concerne a uma estreita análise que se funda ao mesmo tempo sobre a leitura de tradução ou das traduções, que faz aparecer radiograficamente o projeto, e sobre tudo aquilo que o tradutor pôde dizer em textos (prefácios, posfácios, artigos, entrevistas, levando em conta ou não a tradução: tudo é indício), quando esses textos existirem. De fato, há sempre, quando procuramos bem, a palavra do tradutor sobre a tradução, às vezes por interpretar. $\mathrm{O}$ silêncio total é muito raro, segundo Berman. A segunda fase diz respeito ao trabalho comparativo que é, por definição, uma análise da tradução, do original e dos modos de realização do projeto. A verdade e a validade do projeto medemse ao mesmo tempo nela mesma e no seu produto.

\section{A análise propriamente dita da tradução ou a confrontação}

Berman considera essa etapa como parte concreta e decisiva da crítica de traduções: a confrontação fundamentada do original e da sua tradução (fundamentada no sentido de que asseguramos uma série de bases para fazêla). A forma da análise poderá diferir, se tratando por exemplo da tradução de um poema, de um romance, de uma antologia de poemas ou de contos etc. Em todos os casos são analisadas as totalidades, e não os extratos isolados, pontuais. Berman exemplifica seu método com três casos que não são facilmente distinguíveis, segundo ele, dado que a análise de uma tradução de um tradutor dificilmente poderá ser feita sem o exame de suas outras traduções. O trabalho do crítico será diferente, ao se tratar apenas de uma tradução de tradutor (de acordo com os três modos mencionados) ou de uma análise de estudos comparativos com outras traduções da mesma obra. Berman escreve que se pode considerar, por exemplo, os estudos das traduções alemãs de As Flores do Mal (George, Benjamin, etc.). Se a metodologia de base permanecer a mesma, a forma final da análise muda, ou seja, o que é essencial aqui é o fato de comparar a tradução, mesmo que a análise se baseie numa só tradução de uma obra, com outras traduções, quando estas existirem.

A análise da tradução torna-se então a análise de uma retradução, e ela quase sempre o é. Berman afirma que a análise de uma primeira tradução 
é uma análise limitada e imperfeita, e que a imperfeição tradutória e o impacto das "normas" manifestam-se frequentemente porque ela representa ao mesmo tempo introdução e tradução. É por isso que qualquer primeira tradução chama por uma retradução. É na retradução, ou melhor, nas retraduções, sucessivas ou simultâneas, que a tradução se molda. Não somente no espaço da língua/cultura receptora, mas em outras línguas/culturas.

Berman dá o exemplo do horizonte de uma retradução francesa, um horizonte triplo que leva em conta as traduções anteriores, em francês, as outras traduções francesas contemporâneas e as traduções estrangeiras. Ele afirma que não é raro o caso do tradutor consultar as traduções estrangeiras para traduzir tal obra, mesmo sendo a primeira na sua língua. É suficiente mesmo que saiba que a obra já tenha sido traduzida em algum lugar, de modo que a natureza de seu trabalho se altere. Ele não é mais o primeiro. Ambos os casos se apresentaram para Berman quando fez a tradução de $Y_{O}$ el Supremo, de Roa Bastos. Ele diz ter consultado a tradução alemã (anterior), a obra Os diferentes métodos de traduzir de Schleiermacher, bem como a tradução espanhola de V. García Yebra. Quanto à tradução de Sete loucos, de Roberto Arlt, Berman diz que sabia que existiam versões em italiano e em alemão e que a tradução dele seria posterior a estas. Afirma, portanto, que qualquer tradução que vem após outra, mesmo sendo ela estrangeira, é ipso facto uma retradução. É o que faz que existam muito mais retraduções do que primeiras traduções. $\mathrm{O}$ crítico tem que ter em mente que uma análise de tradução é, quase sempre, uma análise de retradução, e que a comparação com outras traduções na análise de uma tradução tem ainda um valor pedagógico. As soluções trazidas por cada tradutor, em função de seus respectivos projetos, são variadas e tão inesperadas que introduzem o crítico, na hora da análise, à dimensão da tradução, que é sempre as traduções, e a dimensão da obra, que existe também no modo da pluralidade. Pedagogicamente falando, esta pluralidade de traduções de um mesmo texto é estimulante, pois, apesar do número elevado de versões dos Sonetos de Shakespeare, eu também posso (re)traduzi-los, diz Berman. Muitas retraduções emergem após a leitura de uma tradução, em poesia principalmente. A 
forma concreta da crítica varia em função dos gêneros de obras traduzidas, das obras específicas referidas etc.

A fase da confrontação se opera, segundo Berman, de quatro modos. Há, em primeiro lugar, uma confrontação dos elementos e das passagens selecionadas no original com os elementos e passagens correspondentes na tradução. Há, em segundo lugar, a confrontação inversa das zonas textuais julgadas problemáticas ou, pelo contrário, perfeitas, da tradução com as zonas textuais correspondentes do original. Essas duas confrontações não têm evidentemente que ser justapostas mecanicamente como as peças de um quebra-cabeça. O terceiro modo da confrontação concerne à confrontação com outras traduções (na maior parte dos casos). E, por último, há a confrontação da tradução com o seu projeto, que faz aparecer o "como" da sua realização, ligado, em última análise, à subjetividade do tradutor e às suas escolhas íntimas: projetos quase idênticos têm sempre traduções diferentes. Ela faz também aparecer aquilo que o projeto rendeu.

Essa última confrontação, conforme Berman, não pretende constatar desacordos ou diferenças entre o projeto e a sua realização, mas sim deve determinar a sua natureza, as suas formas, as suas causas. O mais comum, quando acreditamos descobrir uma divergência, é que nós mesmos tenhamos analisado o projeto e suas consequências de forma incompleta o que ocorre facilmente quando falha a reconstituição hipotética. Mas o que pode aparecer como um desacordo entre o projeto e a tradução é a imperfeição inerente ao ato de traduzir, confirma Berman. Quaisquer que sejam a lógica e a coerência de um projeto, independentemente do projeto, haverá sempre imperfeição numa tradução. Se a ausência de projeto tradutório desencadeia todas as formas de imperfeição, a existência de um projeto não garante nada contra isso. O que também pode parecer um desacordo é a coexistência de partes contraditórias num projeto. Contudo, não podem apenas se tratar de contradições latentes ou locais: quem diz projeto, diz coerência.

Como é num nível final de escolhas pontuais e mais geralmente no contato pontual com o original que age a imperfeição (de onde, sempre, algumas escolhas finais são discutíveis, os erros, os contrassensos, os esquecimentos, os lapsos etc.), não há, avisa Berman, lugar para trazer as 
divergências ao projeto, mas sim à subjetividade do tradutor. Outros pequenos desacordos podem resultar de escolhas de tradução que, temporariamente, violam o projeto para que elas obedeçam a leis diferentes. Esse caso é comum, pois trata-se quase sempre de interferências do discurso da doxa, aquilo de que nenhum tradutor consegue escapar totalmente (por exemplo, quando o tradutor começa a clarificar, alongar, afrancesar). Resumidamente, é a finitude do tradutor que explica os desacordos em relação ao projeto. Mas ele não pode deixar que as discordâncias pontuais se tornem muito numerosas.

Enquanto trabalho de escrita, Berman explica que a confrontação deve enfrentar o problema da sua comunicabilidade, ou seja, da sua legibilidade. Esse terceiro ponto da confrontação envolve o estilo da confrontação, pois esta, como é fácil de constatar lendo muitas análises de traduções, é ameaçada por vários perigos, segundo Berman, como o tecnicismo terminológico com o emprego de termos não explicitados de linguística, de semiótica etc.; a erupção da língua do texto original ou de uma tradução estrangeira evocada; o caráter meticuloso, volumoso e potencialmente asfixiante da análise, e o caráter especializado, isolado da análise, que parece se restringir a comparar sem nenhum questionamento.

No que concerne ao tecnicismo terminológico, que está presente tanto em Meschonnic como em Toury e Brisset, implica uma redução da comunicação, garantindo ao mesmo tempo - nesse caso preciso - um maior rigor do discurso. A tecnicidade de um texto crítico não tem nada de negativo, com toda a sua ferramenta conceitual e, frequentemente, de termos novos ou tirados das mais diversas disciplinas. Tem a sua necessidade, mas ameaça mesmo assim a finalidade fundamental da crítica, que é a de abrir um texto a públicos múltiplos. O crítico de tradução deverá então explicitar, de uma maneira ou de outra, tanto quanto for possível, a sua terminologia e os seus conceitos, para "desermetizar o discurso" como diz Berman

O segundo perigo que pode ser encontrado na análise de traduções é o da erupção ao mesmo tempo abundante e fragmentada da língua do original no discurso traduzido. Não se pode supor que essa língua seja conhecida do leitor ou de todos os leitores. Berman enfatiza o fato de que a crítica deve postular, ainda que não seja empiricamente verdadeiro, que o 
seu primeiro leitor é o leitor da tradução, aquele que precisamente, na maioria dos casos, leu a tradução porque não podia ler o original. Para que a análise seja aberta e fecunda, é necessário que a introdução de fragmentos do original seja acompanhada de certos procedimentos esclarecedores. As retraduções não objetivam tanto corrigir ou oferecer uma solução melhor, como em Meschonnic, mas sim fazer entender prosaicamente o texto estrangeiro. Berman ilustra seu argumento com palavras-chave estrangeiras que são frequentemente intraduzíveis, como o self inglês, ou o goce espanhol, ou o Sehnsucht alemão etc. Essas palavras intraduzíveis devem ser esclarecidas e devem esclarecer também uma palavra fundamental de outra língua (ou seja, estender todo o seu significado) na sua própria língua, ainda que essa palavra não tenha equivalente, ou seja, não tenha uma tradução preestabelecida.

O terceiro perigo com o qual o crítico pode se deparar é se ater a um simples alinhamento arbitrário de pequenas observações. O crítico deve conduzir o leitor num movimento aberto à pluralidade de perspectivas e de horizontes na sua análise comparativa. A confrontação microscópica e concisa de fragmentos do original com fragmentos da tradução não pode gerar tédio no leitor, segundo Berman. Tédio que não teria muita importância se não viesse a impedir a releitura, o ato em si pelo qual nós nos apropriamos verdadeiramente de um texto. É necessário sempre praticar a escrita de maneira a despertar no leitor o desejo de reler.

E, para evitar o último perigo da análise apontado por Berman, ou seja, comparar sem questionamento, este sugere três procedimentos que fazem da análise um verdadeiro trabalho de escrita. O primeiro é a clareza da exposição com os devidos requisitos estilísticos de proibições concretas (evitar o excesso de gíria, as sintaxes empoladas, as elipses - até um certo ponto, ou mais precisamente, até o ponto no qual essas autointerdições não prejudiquem o movimento do pensamento, o rigor que lhe é próprio etc.).

O segundo procedimento é a reflexividade incessante do discurso que afrouxa o confronto original/tradução e se realiza, sobretudo, sob a forma de digressão. Que a análise, no percurso pontual, seja reflexiva, significa em primeiro lugar que não seja uma colagem de textos confrontados (no duplo sentido de se colar neles e de os colar entre si), mas que se afaste sempre para 
esclarecê-los. O terceiro procedimento é a digressividade, que consiste em que, quando houver a necessidade, a partir de um dado exemplo, seja aberta uma série de questões, perspectivas e resumos sobre as quais deve se refletir. A leitura, acrescenta Berman, pode se tornar ora cativante, ora sufocante.

Para tomar um exemplo que será examinado na segunda parte do seu livro, Berman cita dois versos de John Donne e sua tradução em francês:

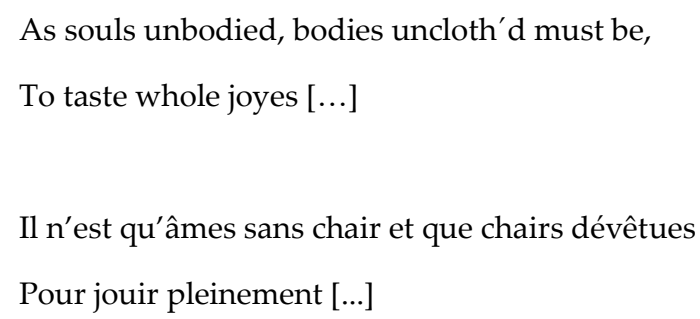

[Há apenas almas sem carne e apenas carnes despidas.

Para desfrutar plenamente... [...] ]

Berman analisa a tradução dos dois versos que sugerem no mínimo três perguntas a respeito das escolhas de traduções operadas em francês: traduzir, primeiro, body por chair (enquanto Donne tematiza a diferença entre body eflesh); em seguida, traduzir to taste whole joyes por jouir pleinement (visto que joy é uma palavra fundamental da poesia de Donne e mesmo a poesia ocidental); e, finalmente, traduzir as palavras negativas, unbodied $\mathrm{e}$ unclothed, postas em equilíbrio em Donne, pela forma fraca sans e depois por uma palavra negativa, dévêtues, sem todavia restituir o paralelismo unbodied/unclothed e sem refletir sobre a existência desse paralelismo. Berman lembra ao leitor que a frequência das palavras negativas em Donne é importante (cinco no poema em questão), como na poesia inglesa e na poesia em geral, sem falar de sua importância na fala coloquial, na mística e na filosofia. Berman afirma ainda que essa reflexão que os tradutores não fizeram, compete ao crítico analista fazê-la para iluminar a passagem do original para o leitor. Isso o fará sentir os desafios poéticos que lá estão, o que pode parecer apenas um único detalhe, criticar com equidade as escolhas 
dos tradutores, e abrir o horizonte para outras escolhas, outras soluções, de outros projetos de tradução.

São as digressões, diz Berman, que ao mesmo tempo permitem à análise se afastar da explicação de texto e assegurar sua autonomia de escrita e lhe conferem o caráter de um comentário ou do que ele chama de comentatividade. Com a reflexividade, a digressividade e a comentatividade entra em jogo no discurso transparente do crítico a sua subjetividade. Porque é somente ele que decide.

Para Berman, a análise, para ser uma verdadeira crítica, deve necessariamente conduzir a uma avaliação do trabalho do tradutor, respondendo ao que esperam os leitores e à natureza de toda leitura de tradução. Acrescenta também que a avaliação, mesmo acompanhada de todas as justificativas possíveis, vai refletir as ideias, as teorias da crítica em matéria de literatura e de tradução. Como não cair (se ela não quer ser neutra) em dogmatismo ou, pelo menos, privilegiar certa concepção de traduzir? Berman acredita que é possível fundamentar a avaliação sobre um duplo critério que escapa desse perigo, ou seja, que não implique nenhuma outra concepção da tradução além desta que, hoje em dia e mesmo ontem, é objeto de um consenso entre os tradutores e todos os que se interessam por tradução. São critérios de ordem ética e poética, num sentido amplo.

A poeticidade de uma tradução reside no fato de o tradutor haver realizado um verdadeiro trabalho textual, em correspondência mais ou menos estreita com a textualidade do original, explica Berman. Esse trabalho textual do tradutor não prejudica absolutamente nem o modo nem a finalidade da tradução4: entre o Lucien de Perrot de Ablancourt, do tipo belle infidèle, as Mil e uma Noites de Galland, o Poe de Baudelaire, o Paraíso Perdido de Chateaubriand, o Hopkins de Leyris, a Odisséia de Jaccottet, a Eneida de Klossowski, a poesia não traduzida de Robin, nenhum ponto em comum, além do que em todos os casos há um trabalho textual e poético no sentido amplo, bem como produção de obras verdadeiras. Mesmo que ele pense que

\footnotetext{
${ }^{4}$ Berman explica o que são finalidade e modo. A finalidade é aqui o objetivo global da tradução: por exemplo, se apropriar de Plutarco, afrancesá-lo, integrá-lo ao patrimônio francês. O modo é o conjunto das estratégias de tradução empregadas para obter esse resultado.
} 
sua obra é apenas um pálido reflexo, que é um eco da obra verdadeira, o tradutor deve sempre desejar fazer uma obra.

A eticidade reside no respeito, ou melhor, em certo respeito ao original, devendo dialogar com ele. Citando Masson (Territoire de Babel. Aphorismes", op.cit., p. 158), Berman escreve que o "texto traduzido é primeiramente uma oferenda feita ao texto original". Em todas as traduções mencionadas, esse respeito que enfrenta o texto e se coloca como uma oferenda está presente. Mas, para o tradutor, tal respeito é a coisa mais difícil, afirma Berman, principalmente por causa da crença de que traduzir é simplesmente respeitar a diversidade do texto e, então, implica sempre a destruição do tradutor e da adesão servil à letra. Mas a eticidade do traduzir é ameaçada pela não-veracidade, pelo engano. São todas as formas de manipulação do original silenciadas, veladas.

Não dizer o que vai fazer - por exemplo, adaptar ao invés de traduzir - ou fazer outra coisa diferente do que disse, eis o que valeu à corporação dos tradutores o adágio italiano traduttore traditore e que o crítico deve denunciar duramente. $\mathrm{O}$ tradutor tem todos os direitos desde que o faça honestamente. Daí Berman dá vários exemplos. Quando Garneau, em seu Macbeth, disse "salto do verso 38 ao 47 porque são medianos (Ato III, sc. 6)" ${ }^{5}$ (BERMAN, 1995, p. 93), não há porque considerar isso como inadmissível: é confessado, e conduz a sua tradução - em parte - para a adaptação. Quando Yves Bonnefoy traduz Sailing to Byzantium, de Yeats, na falta de melhor, por Byzance, l'autre rive, este evoca a liberdade do tradutor. Perrot de Ablancourt não dissimulava de modo algum os seus cortes, os seus acréscimos, os seus embelezamentos etc.: ele os expunha nos seus prefácios e nas suas notas.

Eticidade e poeticidade garantem em primeiro lugar que exista, de uma maneira ou de outra, correspondência com o original e com a sua língua. A palavra correspondência aqui é escolhida de forma voluntária devido à sua rica polissemia e, também, à sua indeterminação, revela Berman. A tradução deve sempre "corresponder", na pluralidade de todas as suas significações. Eticidade e poeticidade garantem em segundo lugar

\footnotetext{
${ }^{5}$ « J'saute du vers 38 au vers 47 parc' c'est mêlé mêlant (Acte III, sc. 6) »
} 
que existe, ainda segundo os termos de Berman, um "fazer-obra" na língua traduzinte que a amplia em todos os níveis onde ocorre. O tradutor atual, escreve, só pode se situar em relação à figura moderna da tradução criada pelos românticos alemães. Pode rejeitá-la, ou seja, traduzir segundo uma figura anterior, aquela da época clássica - Yourcenar, por exemplo, traduz do grego - ou mesmo segundo a Idade Média (realizar apenas a translação dos significados e dos termos, como em tradução especializada) - em qualquer destes, conscientemente ou não, o tradutor age remetendo ao exemplo moderno de traduzir.

Antoine Berman explica, por fim, para o seu leitor que o método de análise que ele criou pode ser seguido de mais duas etapas: a recepção da tradução e a crítica produtiva, etapas que não são comuns a todas as traduções, mas que podem fazer parte da crítica.

A recepção da tradução pode ser autônoma ou integrada a outras etapas, de acordo com o caso. Berman indica que essa etapa não é sempre possível no caso das obras traduzidas, pois há mais recepção de obras estrangeiras, seja na imprensa e nas seções literárias dos diários, dos semanários, nas revistas literárias ou nas obras críticas sobre autores estrangeiros, do que de traduções como tais. Berman adverte que o crítico deve primeiro verificar se a tradução é percebida como uma tradução, se foi avaliada, analisada, ou seja, como apareceu para a crítica e como foi julgada e apresentada ao público. Berman lamenta o pouco volume de críticas de tradução, que são, geralmente, depreciativas.

Quanto à crítica produtiva (termo que Berman toma emprestado a Schlegel), pode ser somente tratada quando uma tradução requerer uma retradução por essa tradução ser insatisfatória, ou porque envelheceu demais. O crítico de literatura traduzida, para Berman, articula os princípios de uma retradução da obra em questão para preparar tradutores que poderão propor um novo projeto de tradução no espaço de jogo da retradução. Quando a tradução é considerada uma boa tradução, ou até uma excelente tradução, a crítica será produtiva na medida em que sua tarefa é a de refletir e avisar o leitor desta excelência. Se a tradução for média ou errônea, o crítico deve explicar as razões, mas sem dar conselhos. 
Berman termina dizendo que só se pode considerar que uma obra é realmente transplantada e implantada, o que não significa que foi integrada ou naturalizada, quando traduzida stricto sensu, e não quando for adaptada. Mas uma tradução só pode ser integrada e ter real atuação nesta línguacultura se for sustentada e acompanhada por trabalhos críticos.

\section{Referências bibliográficas}

BERMAN, Antoine. "Critique des traductions/John Donne". Po\&sie, n 59, Paris, Librairie Classique Eugène Belin, 1992, p. 3-20.

BERMAN, Antoine. Pour une critique des traductions : John Donne. Paris: Gallimard, 1995.

\section{Esquema sintetizado do método de análise de tradução ${ }^{6}$}

1 - Pré-análise da tradução

Leitura e releitura da tradução

- Apontar as zonas textuais problemáticas ou bem-sucedidas.

As leituras do original

- Inclui leituras das demais obras de um autor, trabalhos diversos sobre esse autor, estudos sobre sua época, leitura de outras traduções do tradutor, leituras críticas, informativas.

Seleção de exemplos estilísticos

- Seleção de zonas significantes pertinentes e significativas no original reveladas pelo trabalho interpretativo: num poema, pode ser um verso, num romance, algumas passagens; num conjunto de contos, a frase final da última narrativa; numa peça de teatro, uma ou duas contrapartes que, de uma só vez nos dizem o sentido de toda a obra de maneira precisa.

- Seleção, no texto traduzido, das passagens significativas e das zonas fracas e zonas fortes.

\footnotetext{
${ }^{6}$ Esquema da minha autoria elaborado a partir do método de Berman.
} 
2 - O tradutor e o trabalho de tradução

À procura do tradutor

- Quem é o tradutor? É nacional ou estrangeiro? Exerce outra profissão? É escritor? De quais línguas traduz? É bilíngue? Que tipos de obras traduz? De quais línguas? Escreve artigos, estudos, teses, livros sobre as obras que traduziu? etc.

A posição tradutória

- Visão e conceito de tradução por parte do tradutor.

- O crítico é que reconstitui as posições dos tradutores a partir das traduções e das diversas falas que estes fazem acerca de suas traduções, do traduzir ou de outros temas.

O projeto de tradução

- O projeto ou finalidade da tradução define a maneira pela qual o tradutor traduz e assume a própria tradução.

O horizonte do tradutor

- Experiência, de mundo, de ação e de recontextualização.

- Estudos de tudo que concerne ao autor, gênero traduzido numa época determinada, etc.

3 - A análise propriamente dita da tradução ou a confrontação

Formas da análise

- Diferem segundo se trate da tradução de um poema, de um romance, de uma antologia de poemas ou de contos etc.

- Possibilidade de análise a partir de uma só tradução de uma obra ou com outras traduções (retraduções).

A confrontação

- Confrontação dos elementos e das passagens selecionadas no original com os elementos e passagens correspondentes na tradução;

- Confrontação inversa das zonas textuais julgadas problemáticas ou perfeitas, da tradução com as zonas textuais correspondentes do original;

- Confrontação com outras traduções;

- Confrontação da tradução com o seu projeto de tradução. 
O estilo da confrontação

- Pode sofrer ameaças como o tecnicismo terminológico com o emprego de termos não explicitados de linguística, de semiótica etc.; a erupção da língua do texto original ou de uma tradução estrangeira evocada; o caráter meticuloso, volumoso e potencialmente asfixiante da análise e o caráter especializado, isolado da análise, que parece se restringir a comparar sem nenhum questionamento.

O fundamento da avaliação

- Responde ao que esperam os leitores e à natureza de toda leitura de tradução.

- Avaliar segundo critérios de poeticidade (verdadeiro trabalho textual do tradutor) em correspondência mais ou menos estreita com a textualidade do original e de eticidade, respeito ao original, devendo dialogar com ele.

\section{Resumo}

O presente artigo possui as características ao mesmo tempo de uma "pseudorresenha" pela liberdade ensaística que o gênero possibilita e de uma reescrita produtiva em português, emprestando o qualificativo a Berman, dos textos que escreveu em francês no final do século XX. Entendo o texto que apresento aqui para o leitor como uma atividade processual do reescrever que me fez considerar o fato de que as condições de circulação de um texto fazem parte integrante de sua produção. Portanto, as reflexões a seguir apoiam-se em dois textos seminais e inéditos em português de Antoine Berman em publicações póstumas "Critique des traductions/John Donne", publicado na revista PoEsie em 1992 e o livro Pour une critique des traductions: John Donne em 1995. Com o objetivo de disponibilizar a teoria de Berman sobre a crítica de tradução em língua portuguesa, uso o que chamei de auto resenha que Berman fez sobre o próprio livro, o tornando ao mesmo tempo autor e crítico de si próprio, Pour une critique des traductions: John Donne, isto é, um breve resumo do livro bem como análises detalhadas dos pontos que considerava essenciais à crítica. Divido o texto em três partes, a pré-análise da tradução, o tradutor e o trabalho de tradução e a análise propriamente dito da tradução ou a confrontação, que retomo no final ao 
propor um esquema do método de análise de tradução para sintetizar os passos da crítica do Berman.

Palavras-chave: Antoine Berman; Crítica da tradução; John Donne

\section{Résumé}

Le présent article réunit les caractéristiques à la fois d'une "pseudorecension », en raison de la liberté essayiste que permet le genre, et d'une réécriture productive en portugais, pour emprunter le qualificatif de Berman, des textes qu'il a écrits en français à la fin du vingtième siècle. Je comprends le texte que je présente ici au lecteur comme une activité de processus de réécriture qui m'a fait considérer le fait que les conditions de circulation d'un texte font partie intégrante de sa production. C'est pourquoi les réflexions qui suivent se fondent sur deux textes séminaux et inédits en portugais d'Antoine Berman, publiés à titre posthume : "Critique des traductions/John Donne », publié dans la revue PoEsie en 1992 et le livre Pour une critique des traductions : John Donne en 1995. Dans le but de rendre disponible en langue portugaise la théorie de Berman sur la critique de la traduction, j'utilise ce que j'ai appelé l'auto-recension de Berman sur son propre livre, faisant de lui à la fois l'auteur et son propre critique, Pour une critique des traductions: John Donne, soit un bref résumé du livre ainsi que des analyses détaillées des points qu'il considérait essentiels à la critique. Je divise le texte en trois parties, la pré-analyse de la traduction, le traducteur et le travail de traduction et l'analyse proprement dite de la traduction ou de la confrontation, sur lesquelles je reviens à la fin proposant un schéma de la méthode d'analyse de la traduction pour synthétiser les étapes de la critique de Berman.

Mots-clés : Antoine Berman ; critique de la traduction ; John Donne 